aspects. The operational and tactical, the social, technical and the tragedies in the loss of lives are all there. Although this book is largely the product of his reminiscences it is an important contribution to the role of air power in the named war. It gives the reader an insight into the problems encountered by South Africa cut off from opportunities to buy military hardware anywhere in the world and how the South African Air Force had to compete with adversaries equipped by a superpower, the Soviet Union, in an escalating war.

The story starts with the acquisition of the planes from France, just before the compulsory international arms boycott was proclaimed by the United Nations in 1977. One is astonished by the teething problems that the South African Air Force and the Arms Industry had to overcome to get the planes ready in time for the escalating conflict in Namibia. This is followed by a chronology of the establishment of the Mirage squadrons in the Air Force and the role they played in this war. The end of the war, scaling down an eventual closing of some of the squadrons is also described.

The book major asset is its integration of expertise with personal involvement. For the student of Military History as well as the Air Force personnel who served and want to cherish old memories this book will be read with satisfaction. It will not be the final say on the use of air power in the border war, but it is a good start.

The only disturbing aspects of the book are the use of the word "terrorist" to describe PLAN guerrillas and the fact that certain technical aspects are not always sufficiently explained to the layman.

Vlamgat is an important contribution to the annals of South African military history and the social life of the Namibian border war. I would recommend the book to any student of air power in the contemporary world.

Col (Dr) C.J. Jacobs, Resident Military Historian, South African Army College, Pretoria

\title{
Peacekeeping in Africa: Capabilities and Culpabilities
}

\author{
E.G. Berman \& K.E. Sams
}

United Nations Institute for Disarmament Research (UNIDIR), Geneva, Switzerland and Institute for Security Studies: Pretoria, 2000

540 Pages

Preface

Glossary of terms

Tables, maps, annexes

ISBN 9290451335

African states increasingly carry the responsibility for the promotion and maintenance of peace and security on the African continent. This book provides a 
detailed discussion on the efforts made by African states to do so and explores the ways and means to enhance Africa's peacekeeping capacity. An analysis is also made of external efforts to develop and enhance the capacity of African states to undertake peacekeeping operations. The content of this book is based on a two year research project conducted by means of fieldwork in more than 20 countries and interviews with more than 200 policy makers and members of civil society.

The book is divided into three parts dealing firstly with setting the stage for peacekeeping in Africa. The prospects for peace and security in Africa is discussed in chapter one with specific reference to the legacy of colonialism and the Cold War; the subsequent decline of the state; and the rise in intra-state conflict and its regional implications. The discussion on the latter highlights the need for a collective peacekeeping capacity given the multifaceted and deeply entrenched nature of African conflict and its cross-border implications. In chapter two emphasis is placed on the evolving role of peacekeeping in Africa. The origins of UN peacekeeping, post-Cold War peacekeeping operations (with reference to the classic Somalia experience), the subsequent retreat of the international community from peacekeeping and the increasing reliance on burden-sharing (i.e regional and subregional undertakings) are some of the issues of discussion. Throughout the book the term "peacekeeping" denotes "... a military or a police force deployed at the request of a government or a representative group of political and military actors that enjoys wide international recognition."

African organisations and their ad hoc initiatives are the main focus of part two. Chapters three, four, five and six respectively deals with the Organisation of African Unity (OAU), the Economic Community of West African States (ECOWAS), the Southern African Development Community (SADC) and other subregional organisations. Berman and Sams offer a detailed depiction on the background, purpose, structure and functioning of these organisations. Various examples of peacekeeping operations undertaken by these organisations are discussed in depth (i.e. ECOMOG operations in Sierra Leone and Guinea-Bissau and the military interventions of the SADC member states in Lesotho and the DRC). The authors highlight persistent operational difficulties such as insufficient funding, logistical problems and numerous command and control problems as constraints of effective peacekeeping operations. These shortcomings should be listed as priorities on the security agendas of these organisations. An overview of the mandate and potential of "lesser known" sub-regional organisations (i.e. the Arab Maghreb Union, the Intergovernmental Authority on Development and the Economic Community of Central African States) to deal with conflict prevention, management and resolution, is also noteworthy.

Chapter seven deals with military interventions on the continent undertaken by African countries outside of regional and sub-regional organisations. These African-led multinational forces where deployed in the former Zaire (19771979), Chad (1979) and Mozambique (1986-1992). The inclusion of these ad hoc initiatives in the book is important for two reasons. Firstly, it is an indication of the political will exhibited by African states to deploy troops. Secondly, it highlights the 
limitations of African states to participate in ad hoc military intervention without Western assistance.

Part three deals with the abilities and limitations of African peacekeeping. Chapter eight covers fifty years of UN peacekeeping experience and the lessons learnt, whilst the characteristics of UN peacekeeping operations, which often affect a country's ability to participate, are discussed in chapter nine. The authors provide several detailed tables that elucidate the discussion. These tables include a list of African countries that have provided formed units of infantry troops to UN peacekeeping operations and the names of African heads of military or civilian police components of UN peacekeeping operations.

Efforts by several Western states and other bilateral and multilateral initiatives to develop Africa's peacekeeping capacity form the main theme of part four. Chapters ten, eleven and twelve respectively elaborate on the contributions made by the United States, France and the United Kingdom. These contributions include the US African Crises Response Initiative, which seeks to develop a peacekeeping capacity through the provision of peacekeeping training to national contingents at battalion level. France and the United Kingdom have also launched several initiatives. Berman and Sams make valid assessments of the efforts and contributions of these states to develop Africa's peacekeeping capacity. These assessments are based on an elaborate discussion and critique of the different initiatives undertaken by these states.

In chapter thirteen attention is given to other bilateral initiatives such as the capacity-building programs launched by Belgium, Canada, Denmark, Germany, Italy, Japan, the Netherlands, Norway and Sweden. A clear comparison is made between the capacity-building programs of these countries and that of the US, France and the United Kingdom. These programs vary considerably in terms of their level of financial and political commitment as well as their primary emphasis. Multilateral initiatives to enhance African peacekeeping capabilities are addressed in chapter fourteen. These include the efforts of organisations without African members (i.e. the European Union and the Western European Union) and those with African members (i.e. the Commonwealth, the Community of Portuguese-Speaking Countries and the International Organisation of the Francophonie).

The value and contribution of this book is especially evident in its conclusion. It is clear that African regional and sub-regional organisations are assuming primary responsibility for promoting peace and security. Numerous efforts have been launched but are severely limited. It is thus not a question of whither but how? Berman and Sams offer various recommendations concerning actions to be taken by African and non-African states and organisations. These are feasible recommendations that would definitely enhance Africa's peacekeeping capabilities.

The depth and magnitude of research that preceded the writing of this book is plausible. It is seldom that a topic with a wide scope such as peacekeeping in Africa is so comprehensively dealt with in one book. The detailed footnotes and 
various tables, maps and annexes contribute to the value of this book as excellent reading and reference material.

Ananda Nel, School for Security and Africa Studies, SA Military Academy, University of Stellenbosch 